\title{
Toxic Effects of Opioid and Stimulant Drugs on Undifferentiated PC12 Cells
}

\author{
M.T. OLIVEIRA, ${ }^{a}$ A.C. REGO ${ }^{a}$ M.T. MORGADINHO, ${ }^{b}$ T.R.A. MACEDO, ${ }^{b}$ AND \\ C.R. OLIVEIRA ${ }^{a}$ \\ anstitute of Biochemistry, Faculty of Medicine and Center for Neuroscience and Cell \\ Biology of Coimbra, University of Coimbra, 3004-504 Coimbra, Portugal \\ ${ }^{b}$ Institute of Pharmacology and Experimental Therapeutics, Faculty of Medicine, \\ University of Coimbra, 3004-504 Coimbra, Portugal
}

\begin{abstract}
Cell death and reactive oxygen species production have been suggested to be involved in neurodegeneration induced by the drugs of abuse. In this study we analyze the toxicity of the following drugs of abuse: heroin, morphine, $d$-amphetamine, and cocaine in undifferentiated PC12 cells, used as dopaminergic neuronal models. Our data show that opioid drugs (heroin and morphine) are more toxic than stimulant drugs ( $d$-amphetamine and cocaine). Toxic effects induced by heroin are associated with a decrease in intracellular dopamine, an increase in DOPAC levels, and the formation of ROS, whereas toxic effects induced by amphetamine are associated with a decrease in intracellular dopamine and in ATP/ADP levels. In contrast with cocaine, both amphetamine and heroin induced features of apoptosis. The data suggest that the death of cultured PC12 cells induced by the drugs of abuse is correlated with a decrease in intracellular dopamine levels, which can be associated with an increased dopamine turnover and oxidative cell injury.
\end{abstract}

KEYWORDS: amphetamine; cocaine; dopamine; heroin; morphine; PC12 cells

\section{INTRODUCTION}

Drug addiction is associated with a repeated use of a drug or a combination of drugs. The dopaminergic system has been identified as a critical and shared pathway involved in drug reward, and the drugs prone to abuse have been shown to elevate synaptic dopamine levels in this pathway. ${ }^{1}$ Dopamine can be oxidized by $\mathrm{MAO}_{\mathrm{B}}$ in humans, giving rise to DOPAC and $\mathrm{H}_{2} \mathrm{O}_{2} \cdot{ }^{2}$ Although not a free radical because it does not contain unpaired electrons, $\mathrm{H}_{2} \mathrm{O}_{2}$ can interact with transition metal ions and produce the highly toxic hydroxyl radical $\left({ }^{\circ} \mathrm{OH}\right)$ via the Fenton-Haber Weiss reaction. Therefore, reactive oxygen species (ROS) have been frequently associated with neuronal cell death due to damage to carbohydrates, amino acids, phospholipids, and nucleic acids. Moreover, the rise in $\mathrm{H}_{2} \mathrm{O}_{2}$ levels can be followed by a decrease in the

Address for correspondence: M.T. Oliveira, Institute of Biochemistry, Faculty of Medicine and Center for Neuroscience and Cell Biology of Coimbra, University of Coimbra, 3004-504 Coimbra, Portugal. Voice: 351239 820190; fax: 351239822776.

mteroliv@cnc.cj.uc.pt

Ann. N.Y. Acad. Sci. 965: 487-496 (2002). @ 2002 New York Academy of Sciences. 
levels of reduced glutathione (GSH), which can lead to the inhibition of mitochondrial respiratory chain activity and, subsequently, to cell death. ${ }^{3}$ In addition, dopamine has been shown to induce cell death by apoptosis in several cell types, ${ }^{4-6}$ and to inhibit mitochondrial respiration. ${ }^{7}$

In the present study, using PC12 cells as models of dopaminergic neurons, ${ }^{8,9}$ we explored the effects of toxic concentrations of some opioid and stimulant drugs of abuse — namely, amphetamine, heroin, and cocaine - that are known to cause severe health problems in the Portuguese population. The data highly suggest that toxic effects induced by the drugs of abuse in vitro are associated with a decrease in intracellular dopamine levels, probably related with an enhanced dopamine turnover and oxidative stress.

\section{METHODS}

\section{Culture of Undifferentiated PC12 Cells}

PC12 cells ${ }^{10}$ were cultured in $75 \mathrm{~cm}^{2}$ flasks, in RPMI 1640 medium supplemented with $10 \%(\mathrm{v} / \mathrm{v})$ horse serum, $5 \%(\mathrm{v} / \mathrm{v})$ bovine serum, $50 \mathrm{U} / \mathrm{mL}$ penicillin, and 50 $\mathrm{mg} / \mathrm{mL}$ streptomycin. Cultures were maintained at $37^{\circ} \mathrm{C}$ in a humidified incubator containing $95 \%$ air and $5 \% \mathrm{CO}_{2}$, and passed twice a week. The cells were plated on poly-L-lysine-coated multiwells at a density of 50,000 cells $/ \mathrm{cm}^{2}$ for MTT studies or at a density of 160,000 cells $/ \mathrm{cm}^{2}$ for other studies. For the analysis of chromatin condensation, the cells were incubated in suspension at 180,000 cells $/ \mathrm{mL}$. The cells were further incubated with the drugs of abuse, morphine, heroin, cocaine and amphetamine, for 24,48 or $96 \mathrm{~h}$.

\section{Analysis of Cell Viability}

The integrity of the plasma membrane of PC12 cells was determined by monitoring the leakage of lactate dehydrogenase (LDH), by following the rate of conversion of NADH to NAD ${ }^{+}$at $340 \mathrm{~nm}$, according to Bergmeyer and Brent. ${ }^{11} \mathrm{LDH}$ release into the extracellular medium was expressed as a comparison to the release observed in control conditions. Cell viability was also measured using the 3-(4,5-dimethylthiazol-2-yl)-2,5-diphenyltetrazolium bromide (MTT) reduction assay at $570 \mathrm{~nm} .{ }^{12}$ The capacity of treated cells in reducing the tetrazolium salt was expressed as a percentage of absorbance in control cells.

\section{Measurement of ATP/ADP Levels}

Intracellular adenine nucleotides, ATP and ADP, were determined after cell extraction with $0.3 \mathrm{M}$ perchloric acid $\left(0-4^{\circ} \mathrm{C}\right)$. The cells were centrifuged at $15,800 \mathrm{~g}$ for $10 \mathrm{~min}$, and the pellet was solubilized with $1 \mathrm{M} \mathrm{NaOH}$ for total protein analysis using the Sedmak method. ${ }^{13}$ The supernatants were neutralized with $10 \mathrm{M} \mathrm{KOH}$ in $5 \mathrm{M}$ Tris, and centrifuged at $15,800 \mathrm{~g}$ for $10 \mathrm{~min}$. The resulting supernatants, stored at $-80^{\circ} \mathrm{C}$, were assayed for ATP and ADP determination by separation in a reversephase HPLC, as described previously. ${ }^{14}$ 


\section{Analysis of Chromatin Condensation}

Analysis of neuronal cell death by necrosis and/or apoptosis was assessed using the fluorescent probes SYTO-13 (Molecular Probes) and PI (propidium iodide). SYTO-13 labels RNA and DNA in living cells with an UV-excited green emission. Propidium iodide is excluded from viable cells, with an UV-excited red emission. The cells were loaded for $3 \mathrm{~min}$ with a solution of sodium medium (in $\mathrm{mM}$ ): $140 \mathrm{NaCl}, 5 \mathrm{KCl}, 1 \mathrm{MgCl}_{2}, 1 \mathrm{NaH}_{2} \mathrm{PO}_{4}, 1.5 \mathrm{CaCl}_{2}, 5.6$ glucose, 20 HEPES (pH 7.4), containing $4 \mu \mathrm{M}$ SYTO-13 and $4 \mu \mathrm{g} / \mathrm{mL}$ PI. The cells were visualized by confocal microscopy.

\section{Measurement of Intracellular Dopamine and DOPAC Levels}

The levels of intracellular dopamine and DOPAC were determined after cell extraction with $0.1 \mathrm{M}$ perchloric acid $\left(0-4^{\circ} \mathrm{C}\right)$. The cells were centrifuged at 15,800 $\mathrm{g}$ for $10 \mathrm{~min}$, and the pellet was solubilized with $1 \mathrm{M} \mathrm{NaOH}$ for total protein analysis using the Sedmak method. ${ }^{13}$ The resulting supernatants, stored at $-80^{\circ} \mathrm{C}$, were assayed for dopamine and DOPAC analysis by liquid chromatography with electrochemical detection, as described previously. ${ }^{15}$

\section{Analysis of Intracellular Production of ROS}

The cells were loaded with the membrane-permeant $\mathrm{DCFH}_{2}$-DA $\left(2^{\prime}, 7^{\prime}\right.$-dichlodihydrofluorescein-diacetate, $20 \mu \mathrm{M}$ ), which allows the detection of intracellular reactive oxygen species (ROS) after the cleavage of diacetate by cytosolic esterases. In the presence of intracellular peroxides, $\mathrm{DCFH}_{2}$ is oxidized to the fluorescent dichlorofluorescein (DCF). The increase in cell fluorescence was measured during $10 \mathrm{~min}$, at $37^{\circ} \mathrm{C}$, with excitation at $502 \mathrm{~nm}$ and emission at $550 \mathrm{~nm}$, using a SPEX Fluorolog spectrometer. The changes in fluorescence were calculated in arbitrary units in relation to the initial values.

\section{Statistical Analysis}

Data are the means \pm SEM from at least two experiments, performed in duplicate or triplicate. Statistical analysis was performed by the one-way ANOVA test ( $p$ $<0.05$ was considered significant).

\section{RESULTS}

FIGURE 1 shows the changes in cell viability induced by the opioid (heroin and morphine) and stimulant (cocaine and amphetamine) drugs, as evaluated by the MTT assay. All the drugs of abuse induced a dose-dependent decrease in cell viability after four days of exposure. Nevertheless, the opioids were shown to be more toxic to PC12 cells than the stimulant drugs, as determined by the analysis of the $\mathrm{IC}_{50}$ values: $\mathrm{IC}_{50} \sim 10^{-4.2}$ (street heroin) $<\mathrm{IC}_{50} \sim 10^{-3.3}$ (heroin) $<\mathrm{IC}_{50} \sim 10^{-3.2}$ (morphine) $\mathrm{IC}_{50} \sim 10^{-2.9}$ ( $d$-amphetamine) $<\mathrm{IC}_{50} \sim 10^{-2.5}$ (cocaine). Interestingly, street heroin was shown to be the most toxic of the drugs tested (FIG. 1), probably due to the presence of toxic contaminants. 


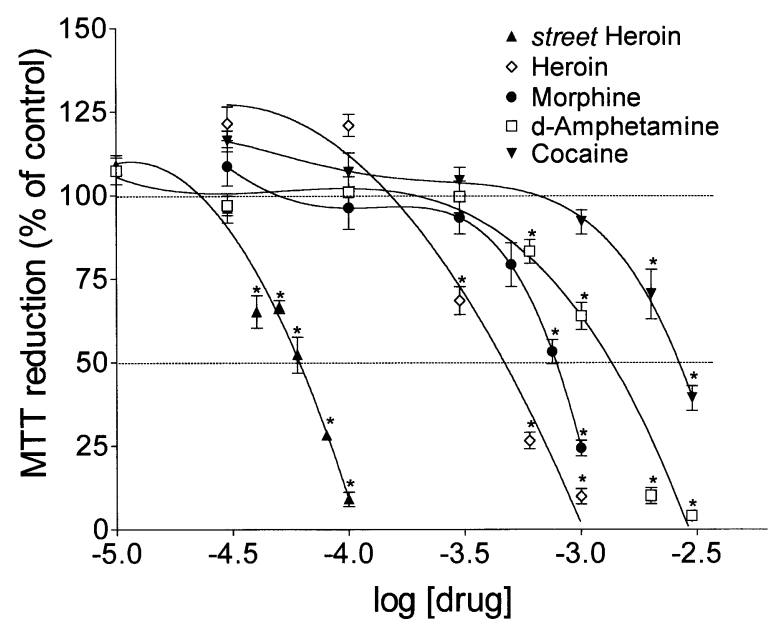

FIGURE 1. Dose-response curves of cytotoxic effects induced by the drugs of abuse. PC12 cells were incubated with increasing concentrations of street heroin, heroin, morphine, amphetamine, or cocaine for four days, and the toxic effects were evaluated by the MTT reduction assay. Data are the means \pm SEM of 3-5 experiments performed in triplicate. Statistical significance: ${ }^{*} P<0.001$ as compared to the control.

The toxic effects of the drugs were further examined by following the leakage of LDH to the extracellular medium (FIG. 2), a known test that evaluates the changes in cell membrane integrity. Concentrations of the drugs close to the $\mathrm{IC}_{50}$ values were used. The drugs amphetamine, heroin, and cocaine were chosen because they are known to cause severe health problems in the Portuguese population. The results show that exposure to concentrations up to $600 \mu \mathrm{M}$ heroin, $3 \mathrm{mM}$ cocaine, or $2 \mathrm{mM}$ amphetamine for four days does not significantly alter the integrity of the plasma membrane of PC12 cells, as compared to the controls, in the absence of the drugs of abuse (FIG. 2).

Analysis of the ratio ATP/ADP is a good indicator of the metabolic status of the cells. Although the exposure to cocaine or heroin did not significantly change this ratio, amphetamine induced a significant decrease (by about 45\%) in intracellular ATP/ADP levels (FIG. 3).

Apoptotic cell death has been shown to play an important role in the pathogenesis of several diseases in the central nervous system (CNS). However, the role of apoptosis in the toxic effect of drugs of abuse, heroin, amphetamine, and cocaine, in dopaminergic cells has not been fully addressed. Accordingly, we have also analyzed the condensation of chromatin, a characteristic feature of apoptosis, by using the SYTO-13/PI assay. As a positive control, serum withdrawal for $48 \mathrm{~h}$ induced a pronounced condensation of the chromatin in PC12 cells, as observed by the labeling with SYTO-13. Similar features of apoptosis were observed in cells incubated in the presence of heroin or amphetamine, but not in the presence of cocaine (FIG. 4). Interestingly, only a very small percentage of cells incubated in serum-free medium 

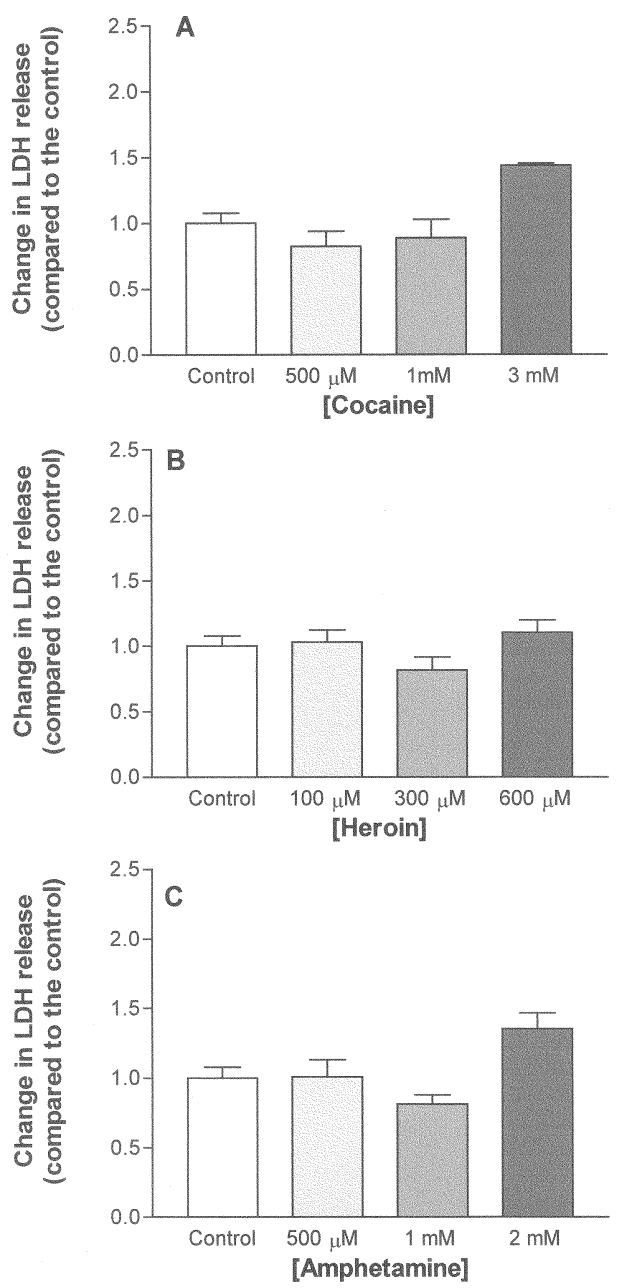

FIGURE 2. Evaluation of membrane integrity upon exposure of the cells to different concentrations of the drugs of abuse. Membrane integrity was measured by LDH release, after exposure of the cells for four days to (A) cocaine $(500 \mu \mathrm{M}, 1 \mathrm{mM}$, and $3 \mathrm{mM})$; (B) heroin $(100 \mu \mathrm{M}, 300 \mu \mathrm{M}$, and $600 \mu \mathrm{M})$; or $(\mathrm{C})$ amphetamine $(500 \mu \mathrm{M}, 1 \mathrm{mM}$, and $2 \mathrm{mM})$. Data are the means \pm SEM of two experiments performed in triplicate.

were shown to be labeled with PI, a nonpermeable fluorescent dye and a marker of necrotic cells.

Because the drugs of abuse interfere with the uptake systems (cocaine ${ }^{16}$ ), or the synaptic vesicle accumulation of dopamine (amphetamine ${ }^{17}$ and cocaine ${ }^{16}$ ), which can induce changes in dopamine neuronal content, we have used the PC12 cells as models of dopaminergic neurons ${ }^{8,9}$ to determine the changes in intracellular dopamine levels upon incubation with heroin, amphetamine, or cocaine (FIG. 5). Exposure 


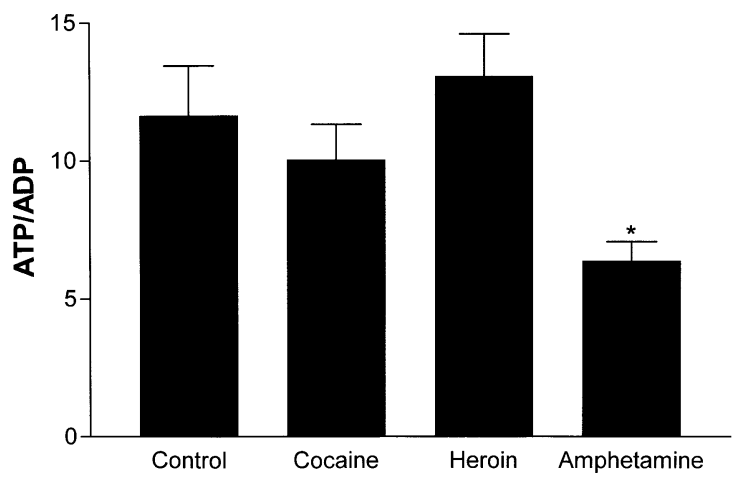

FIGURE 3. Intracellular ATP/ADP levels in PC12 cells incubated with $3 \mathrm{mM}$ cocaine, $300 \mu \mathrm{M}$ heroin, or $1 \mathrm{mM}$ amphetamine for four days. Data are the means \pm SEM of four experiments performed in triplicate. Statistical significance: ${ }^{*} P<0.05$ as compared to the control.
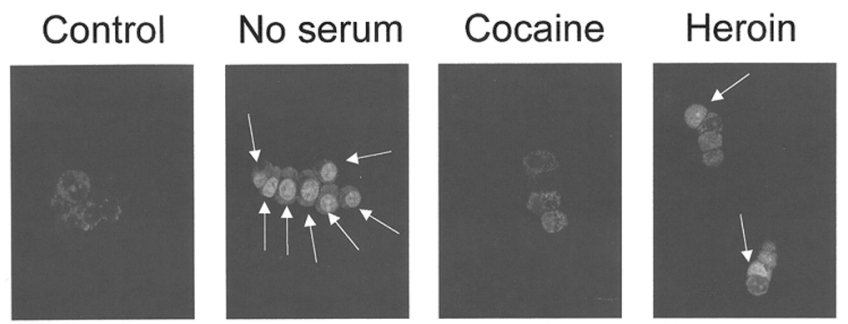

Amphetamine
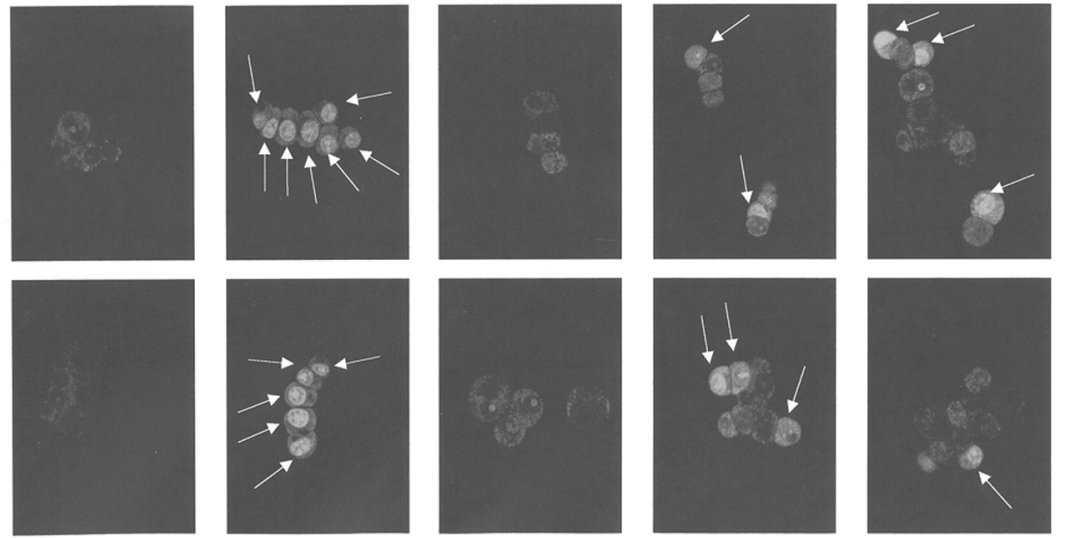

FIGURE 4. Analysis of chromatin condensation in PC12 cells exposed to the drugs of abuse. SYTO-13 and propidium iodide (PI) were used to evaluate apoptotic cell death upon exposure to cocaine $(3 \mathrm{mM})$, heroin $(300 \mu \mathrm{M})$, or amphetamine $(1 \mathrm{mM})$ for $48 \mathrm{~h}$. The cells were incubated in the absence of serum for $48 \mathrm{~h}$ (no serum). All PC12 cells shown in the pictures are labeled with SYTO-13 (green fluorescence). Only a small percentage of cells incubated with medium without serum were found to be labeled with PI (red fluorescence). The arrows indicate PC12 cells showing chromatin condensation. 


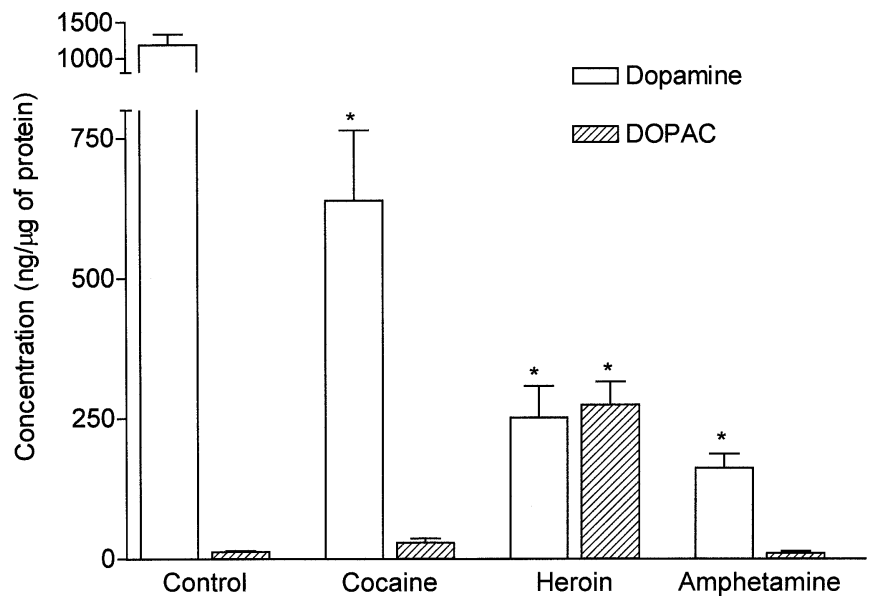

FIGURE 5. Intracellular dopamine and DOPAC levels upon exposure to the drugs of abuse. The cells were incubated with cocaine $(3 \mathrm{mM})$, heroin $(300 \mu \mathrm{M})$ or amphetamine $(1$ $\mathrm{mM})$ for four days. Data are the means \pm SEM of four experiments performed in triplicate. Statistical significance: ${ }^{*} p<0.05$, as compared to the respective control.

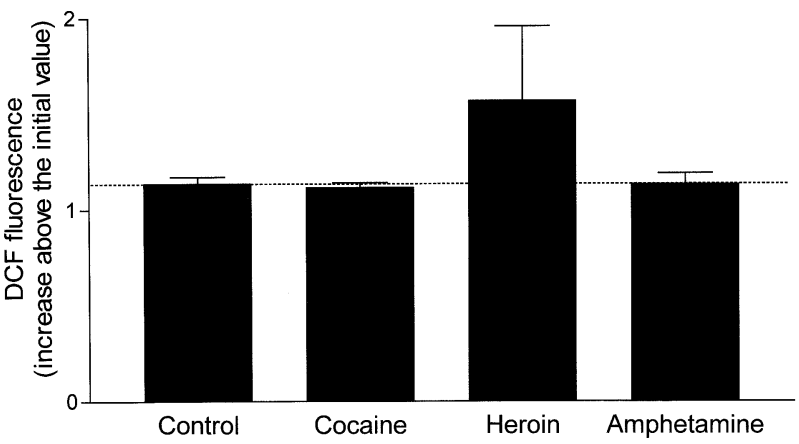

FIGURE 6. Analysis of ROS formation in cells incubated with the drugs of abuse. The oxidation of the probe $\mathrm{DCFH}_{2}(20 \mu \mathrm{M})$ to DCF was followed in cells incubated with $3 \mathrm{mM}$ cocaine, $300 \mu \mathrm{M}$ heroin, or $1 \mathrm{mM}$ amphetamine for $24 \mathrm{~h}$. Data are the means \pm SEM of three experiments performed in triplicate.

to cocaine decreased the dopamine levels by about $40 \%$, whereas exposure to heroin and amphetamine largely decreased dopamine levels, by about $80 \%$. In addition, an increase in intracellular DOPAC levels, suggesting an enhanced turnover of dopamine by MAO, followed the decrement in dopamine upon incubation with heroin. These data also suggested an increased formation of intracellular peroxides. Therefore, we measured the intracellular oxidation of $\mathrm{DCFH}_{2}$ (FIG. 6). Although not statistically significant, the results show an increase in intracellular peroxides in the 
presence of heroin, as compared to control conditions. Changes in basal DCF fluorescence were not observed after the incubation with cocaine or amphetamine. These data indicate that an increased formation of intracellular peroxides may follow the increase in intracellular DOPAC resulting from dopamine metabolization upon exposure to heroin.

\section{DISCUSSION}

In this study we show that cell death induced by the drugs of abuse involves a decrease in intracellular dopamine content in cultured undifferentiated PC12 cells, without major changes in membrane integrity, suggesting an alteration in dopamine metabolic pathways and/or an increase in extracellular dopamine accumulation.

Cytotoxic effects induced by cocaine were not very evident in PC12 cells, as demonstrated by the maintenance of MTT reduction or ATP/ADP levels, the nonappearance of apoptotic features or the small decrease in intracellular dopamine, in contrast with heroin or amphetamine. Nevertheless, cocaine was previously shown to induce cell death by apoptosis in several cell types, including fetal mouse cortical neurons, ${ }^{18}$ fetal rat myocardial cells, ${ }^{19,20}$ bovine coronary artery endothelial cells, ${ }^{21,22}$ or in rat testes. ${ }^{23}$ Moreover, cocaine, and in particular its $\mathrm{N}$-oxidative metabolites, were shown to depress mitochondrial respiration. ${ }^{24}$

Cytotoxic effects induced by heroin were associated with a large decrease in intracellular dopamine, an increase in DOPAC levels, and an apparent, nonstatistical increase in intracellular ROS production. In addition, toxic effects induced by amphetamine in PC12 cells were associated with a decrease in intracellular dopamine and a decrease in ATP/ADP levels, suggesting a certain degree of metabolic dysfunction. Interestingly, both amphetamine and heroin induced chromatin condensation, a feature of apoptotic cell death, which is in agreement with previous studies showing the induction of apoptotic cell death by heroin ${ }^{25}$ and amphetamine. ${ }^{26}$ Furthermore, although our data show an attenuation of ATP production and the appearance of apoptotic features upon exposure to amphetamine, recent data reported by Lotharius and $\mathrm{O}^{\prime}$ Malley $^{27}$ support the idea that amphetamine-induced toxicity in dopaminergic neurons involves production of ROS, although neither protein oxidation, ATP decrement, mitochondrial dysfunction, nor cell death was observed.

In conclusion, toxic effects of amphetamine and heroin in undifferentiated PC12 cells are associated with the induction of apoptotic cell death, which may be due to a metabolic dysfunction induced by amphetamine or an increase in dopamine metabolization and production of ROS induced by heroin. As for cocaine, further experimental approaches are needed to clarify the cytotoxic mechanisms. The results reported in this study are compatible with the hypothesis that dopamine plays a major role in reinforcing the toxic effects of the drugs of abuse.

\section{REFERENCES}

1. Di Chiara, G. \& A. Imperato. 1988. Drugs abused by humans preferentially increase synaptic dopamine concentrations in the mesolimbic system of freely moving rats. Proc. Natl. Acad. Sci. USA 85: 5274-5278. 
2. Olanow, C.W. \& W.G. Tatton. 1999. Etiology and pathogenesis of Parkinson's disease. Annu. Rev. Neurosci. 22: 123-144.

3. CAdet, J.L. \& C. BRANNOCK. 1998. Free radicals and the pathobiology of brain dopamine systems. Neurochem. Int. 32: 117-131.

4. Luo, Y. et al. 1998. Dopamine induces apoptosis through an oxidation-involved SAPK/JNK activation pathway. J. Biol. Chem. 273: 3756-3764.

5. LuO, Y. et al. 1999. Intrastriatal dopamine injection induces apoptosis through oxidation-involved activation of transcription factors AP-1 and NF-kappaB in rats. Mol. Pharmacol. 56: 254-264.

6. LEE, H.J. et al. 2001. Antiapoptotic role of NF-kappaB in the auto-oxidized dopamineinduced apoptosis of PC12 cells. J. Neurochem. 76: 602-609.

7. Ben-Shachar, D., R. Zuk \& Y. Glinka. 1995. Dopamine neurotoxicity: inhibition of mitochondrial respiration. J. Neurochem. 64: 718-723.

8. Takashima, A. \& T. Koike. 1985. Relationship between dopamine content and its secretion in PC12 cells as a function of cell growth. Biochim. Biophys. Acta 847: 101-107.

9. Shafer, T.J. \& W.D. AtChison. 1991. Transmitter, ion channel and receptor properties of pheochromocytoma (PC12) cells: a model for neurotoxicological studies. Neurotoxicology 12: 473-492.

10. GREENE, L.A. \& A.S. TischleR. 1976. Establishment of a noradrenergic clonal line of rat adrenal pheochromocytoma cells which respond to nerve growth factor. Proc. Natl. Acad. Sci. USA 73: 2424-2428.

11. BERgMEYER, H.U. \& E. BERNT. 1974. Lactate dehydrogenase UV assay with pyruvate and NADH. In Methods in Enzymatic Analysis, Vol. 2: 574-579. Academic Press. New York.

12. Mosmann, T. 1983. Rapid colorimetric assay for cellular growth and survival: application to proliferation and cytotoxicity assays. J. Immunol. Methods 65: 55-63.

13. Sedmak, J.J. \& S.E. Grossberg. 1977. A rapid, sensitive, and versatile assay for protein using coomassie brilliant blue G250. Anal. Biochem. 79: 544-552.

14. Fowler, J.C. 1993. Changes in extracellular adenosine levels and population spike amplitude during graded hypoxia in the rat hippocampal slice. Naunyn Schmiedebergs Arch. Pharmacol. 347: 73-78.

15. Morgadinho, M.T., C.A. Fontes Ribeiro \& T.R.A. Macedo. 1999. Presynaptic dopamine receptors involved in the inhibition of noradrenaline and dopamine release in the human gastric and uterine arteries. Fund. Clin. Pharmacol. 13: 662-670.

16. Brown, J.M., G.R. Hanson \& A.E. Fleckenstein. 2001. Regulation of the vesicular monoamine transporter-2: a novel mechanism for cocaine and other psychostimulants. J. Pharmacol. Exp. Ther. 296: 762-767.

17. Jones, S.R., R.R. Gainetdinov, R.M. Wightman \& M.G. Caron. 1998. Mechanisms of amphetamine action revealed in mice lacking the dopamine transporter. J. Neurosci. 18: $1979-1986$.

18. Nassogne, M.C., J. Louahed, P. Evrard \& P.J. Courtoy. 1997. Cocaine induces apoptosis in cortical neurons of fetal mice. J. Neurochem. 68: 2442-2450.

19. Xiao, Y., J. He, R.D. Gilbert \& L. Zhang. 2000. Cocaine induces apoptosis in fetal myocardial cells through a mitochondria-dependent pathway. J. Pharmacol. Exp. Ther. 292: 8-14

20. Zhang, L., Y. Xiao \& J. He. 1999. Cocaine and apoptosis in myocardial cells. Anat. Rec. 257: 208-216.

21. He, J., Y. Xiao, C.A. Casiano \& L. Zhang. 2000. Role of mitochondrial cytochrome c in cocaine-induced apoptosis in coronary artery endothelial cells. J. Pharmacol. Exp. Ther. 295: 896-903.

22. He, J., Y. XiaO \& L. Zhang. 2001. Cocaine-mediated apoptosis in bovine coronary artery endothelial cells: role of nitric oxide J. Pharmacol. Exp. Ther. 298: 180-187.

23. Li, H. et al. 1999. Cocaine induced apoptosis in rat testes. J. Urol. 162: 213-216.

24. Boess, F., F.M. NDIKUM-MofFor, U.A. Boelsterli \& S.M. RoberTs. 2000. Effects of cocaine and its oxidative metabolites on mitochondrial respiration and generation of reactive oxygen species. Biochem. Pharmacol. 60: 615-623. 
25. FeChO, K. \& D.T. LySLE. 2000. Heroin-induced alterations in leukocyte numbers and apoptosis in the rat spleen. Cell Immunol. 202: 113-123.

26. StUmM, G. et al. 1999. Amphetamines induce apoptosis and regulation of bcl-x splice variants in neocortical neurons. FASEB J. 13: 1065-1072.

27. Lotharius, J. \& K.L. O'Malley. 2001. Role of mitochondrial dysfunction and dopamine-dependent oxidative stress in amphetamine-induced toxicity. Ann. Neurol. 49: 79-89. 